\title{
Genetic and Environmental Determinants of Beef Quality-A Review
}

\author{
Tomasz Sakowski ${ }^{1}$, Grzegorz Grodkowski ${ }^{2}$, Marcin Gołebiewski ${ }^{2}$, Jan Slósarz ${ }^{2}$, \\ Piotr Kostusiak ${ }^{2}$, Paweł Solarczyk ${ }^{2}$ and Kamila Puppel ${ }^{2 *}$
}

${ }^{1}$ Department of Biotechnology and Nutrigenomics, Institute of Genetics and Animal Biotechnology, Jastrzebiec, Poland,

${ }^{2}$ Department of Animal Breeding, Institute of Animal Sciences, Warsaw University of Life Sciences, Warsaw, Poland

OPEN ACCESS

Edited by:

$\mathrm{Min} \mathrm{Du}$,

Washington State University,

United States

Reviewed by:

Paulina Pogorzelska-Przybyłek, University of Warmia and Mazury in

Olsztyn, Poland

Monika Sobczuk-Szul,

University of Warmia and Mazury in

Olsztyn, Poland

*Correspondence:

Kamila Puppel

kamila_puppe/@sggw.edu.p

Specialty section:

This article was submitted to

Livestock Genomics,

a section of the journal

Frontiers in Veterinary Science

Received: 21 November 2021

Accepted: 12 January 2022

Published: 24 February 2022

Citation:

Sakowski T, Grodkowski G,

Gołebiewski M, Slósarz J, Kostusiak P, Solarczyk P and Puppel K (2022)

Genetic and Environmental Determinants of Beef Quality-A Review. Front. Vet. Sci. 9:819605. doi: 10.3389/fvets.2022.819605
The flavor, quality, and composition of beef changes with the cattle diet regimen. The quality of meat varies, and that variability is determined by both individual and environmental factors: age, breed, live weight, fatness degree, plane of nutrition, and concentrate/roughage ratio. The strategy for the rearing and feeding of cattle for slaughter should therefore aim at reducing the saturated fatty acid content and increasing the polyunsaturated fatty acid and monounsaturated fatty acid levels. Many diseases in humans, like atherosclerosis and cardiovascular diseases, are associated with dietary fat, and their development process could take a year, the results of which can be a shorter life and its lower quality. The objective of this review was to describe the factors affecting the meat quality and fatty acid profile of the intramuscular fat of European cattle fed various diets.

Keywords: red meat, quality, beef, fatty acid composition, breed

\section{INTRODUCTION}

According to Directive 2001/101/EC ${ }^{1}$, products containing more connective tissue and fat should be labeled as "mechanically separated meat." In the case of beef, the term "good quality of meat" means that the meat is free from all quality defects and that it is originated from healthy animals. All changes occurred correctly at an appropriate pace both in the living animals and in the slaughtered carcasses. It also means that the meat has been cut from the carcass and delivered for consumption or processing after reaching a sufficient degree of ripeness. Listrad et al. (1) pointed out that the quality of the meat can be described by 4 terms: security, healthiness (nutritional quality), sensory quality, and serviceability.

Meat is a mixture of several compounds, but its basic ingredients include water (70-76\%), protein (18-23\%), nitrogen compounds (1-3\%), carbohydrates $(0.5-2 \%)$, muscle fat $(0.7-10 \%)$, and mineral components $(0.5-2 \%)$. The development of the basic chemical composition of meat and thus the development of its nutritional quality are influenced by many factors, both genetic and environmental (1-5).

Water is the predominant component of beef, accounting for $\sim 70-76 \%$. It occurs in a bound form (indistinguishable by centrifugation and pressure) and in the free form. Differences in water concentration in muscle tissue result primarily from the different content of intramuscular fat.

${ }^{1}$ Dyrektywa Komisji 2001/101/WE z dnia 26 listopada 2001 r. zmieniajaca dyrektywe 2000/13/WE Parlamentu Europejskiego i Rady w sprawie zblizenia ustawodawstw Państw Członkowskich odnoszacych sie do etykietowania, p., Ed. 
In addition, the age of the animals also shapes the level of this parameter, because the water content decreases with the age of the animals (6).

The total protein content of meat is in the range of 15$23 \%(7-9)$. It is believed that white meat is healthier than red meat. However, when assessing the healthiness of meat, protein content in particular types of meat is important, but not the most important factor. Beef is characterized by a better amino acid profile compared to other meats. It contains significantly more branched-chain amino acids, including valine, leucine, and isoleucine. Beef is also a rich source of amino acids that pass through the blood/cerebrospinal fluid barrier (10).

Beef meat is characterized by moderate and quite varied fat content, ranging between 0.6 and $23.3 \%$ weight of tissue (11). Fat content changes with age and intensity of nutrition (12). In late-maturing (large caliber) animals, the growth phase, which is characterized by high fat deposition, is shifted over time, so it is possible to link it to high body weight without worrying about lowering the carcass quality. Individual breeds differ from each other in the composition of intramuscular fat as well as the ratio between the different types of fibers. Late-maturing breeds such as Belgian Blue, Limousine, and Blonde d'Aquitaine are characterized by a better muscle tone and less fat (13) compared to those achieved by early-maturing breeds such as Angus. In addition, studies have shown a relationship of singlenucleotide polymorphism in candidate genes (calpastatin) with tenderness (14).

A unique feature of meat is its hydrophilicity, that is, the ability to bind and add water. Water absorption is a factor shaping the organoleptic characteristics of meat. During the ripening process, the ability of meat to bind water increases as a result of loosening the muscle protein grid (15).

The color of meat is one of the meat characteristics that are firstly evaluated by the consumer and, on this basis, shapes the image of the culinary applications of the meat (16). The color is a factor of the age of the animal, its nutrition, the conditions of keeping the animals before slaughtering, and the conditions of ripening. Meat becomes darker with age, changing color from red to dark red (15). Fresh beef should have a bright red color, which is mainly formed by the concentration and form of myoglobin and, to a lesser extent, by hemoglobin (the content in meat ranges from 6 to $16 \%$ of total heme coloration and mainly depends on the anatomical origin of the meat) and cytochrome c (17). Myoglobin ( $\mathrm{Mb})$ is a water-soluble hemoprotein that occurs in skeletal and cardiac muscles. Myoglobin concentration is determined by the species, breed, age, sex, feeding system, and physical activity of the animal. Cow muscles contain more myoglobin than heifers, bulls, or wolves. Myoglobin is at the level of $1-3 \mathrm{mg} / \mathrm{g}$ in muscles in calves, $6-10 \mathrm{mg} / \mathrm{g}$ in young cattle for slaughter, and $16-20 \mathrm{mg} / \mathrm{g}$ in cows for slaughter (18). Myoglobin occurs in three forms of redox: deoxymyoglobin $(\mathrm{DMb})$, oxymyoglobin, and metmyoglobin (MMb). In turn, the redox form depends on the presence of a ligand connected to the iron atom of hem and on the value of iron $\left(\mathrm{Fe}^{2+}\right.$, $\mathrm{Fe}^{3+}$ ). Deoxymyoglobin is a purple-red pigment which retains its form in fresh meat only at a low partial oxygen pressure of $<1.4 \mathrm{mmHg}$. In the presence of oxygen, DMb is spontaneously oxidized to oxymyoglobin (19). When both ferrous myoglobin derivatives are oxidized to iron $\left(\mathrm{Fe}^{3+}\right)$, it is transformed into metmyoglobin. $\mathrm{MMb}$ is the most undesirable form of heme pigment in muscles both in the vital period and in the postmortem period (20). The formation of $\mathrm{MMb}$ is maximal when the partial pressure of oxygen is about $4 \mathrm{mmHg}$ (18). Metmyoglobin is reduced by a complex of MMb reductase, cytochrome b5, and NADH. It should be noted that higher physical activity in the vital period increases the reductase activity (19). The stabilization of meat color in the post-mortem period depends on the activity of $\mathrm{MMb}$ reductase, which is the highest in the temperature range of $30-37^{\circ} \mathrm{C}$. Both the higher antioxidant potential of the meat and its storage in the dark increase its activity (18). In addition, the muscles differ in color stability, where the highest stability is attributed to $\mathrm{m}$. longissimus dorsi, followed by $\mathrm{m}$. semimembranosus and $\mathrm{m}$. gluteus medium, and the lowest to $\mathrm{m}$. psoas major. The structure of the muscle proteins is also important and is a function of $\mathrm{pH}$ values; a dark color is accompanied by higher $\mathrm{pH}$ values $(18,21)$.

The $\mathrm{pH}$ value of the meat reflects the changes that occur after slaughter, i.e., the degree of maturity of the meat and its durability and usefulness. The lactic acid formed during anaerobic glycogenolysis acidifies the environment, and this process may last until the glycogen stores are exhausted or glycolytic enzymes are inactivated by a low $\mathrm{pH}$. During these transformations, the $\mathrm{pH}$ of meat decreases from 7.0 to 5.55.6. The glycogen content significantly determines the final $\mathrm{pH}$ of the meat and the degree of protein proteolysis. In addition, it significantly affects water absorption, fat emulsifiability, tenderness and juiciness, taste, and smell. If the $\mathrm{pH}$ value is lowered too quickly, meat with a watery structure (piles, soft, exudative meat) will occur (18). However, the slower rate of glycolysis and changes in $\mathrm{pH}$ is the reason for the occurrence of dark, firm, dry (DFD) meat. Post-mortem proteolysis during meat maturation is a function of $\mathrm{pH}$ and temperature (16). The degree of acidification of the meat mainly affects the extent of the proteolysis, while the temperature of the environment influences its rate. Transport and pre-slaughter stress are factors that significantly increase the glycogen levels in the muscles after slaughter. At pH24 ( $24 \mathrm{~h}$ after slaughter), values above 6.0 are considered to be typical of DFD meat. This meat has a limited shelf-life (it may spoil after 7 days of refrigerated storage), is susceptible to bacterial spoilage, and is not suitable for the production of durable products (18). In addition, the dark, unnatural color negatively affects the appearance of the meat. Too advanced processes of meat maturation accompanied by the multiplication of microflora lead to its rotting decompositionsuch meat is not fit for consumption. The characteristic features of this process are the appearance of stickiness and mucus on the surface of the meat, a change in smell (the release of unpleasant gases with a scent of hydrogen sulfide and ammonia), a visible change in color to dark red with a greenish or yellow tinge, and a meat $\mathrm{pH}$ exceeding 6.5 (16-18). Additionally, Rutherford et al. (22) reported that the rumen temperature can be used as a predictor of meat quality. Bulls with a greater rumen temperature during the pre-slaughter phase produced meat with a significantly higher $\mathrm{pH}_{\mathrm{ult}}$. The flavor, quality, and composition 
of beef changes with cattle diet regimen (2). The types of forage fed to cattle affect both the carcass characteristics and gains. Beef quality, including its fatty acid composition, has recently been the focus of the interest of many researchers and customers. The genetic variability in beef quality has been linked to differences between lines or breeds, variations due to the crossing of breeds, and variations between animals (23). Differences between many breeds of cattle have been reported for Red Angus and Simmental steers (24), Aberdeen Angus, Belgian Blue, and Limousine bulls (25) and for different double-muscle genotype bulls (26).

Structural changes in the connective tissue are associated with the activity of cathepsin enzymes (21). Calpaine activity is responsible for the alteration of the proteolytic cytoskeletal and regulatory proteins of myofiber (27). In the skeletal muscle of the animals, 3 major types of calpains have been identified: $\mathrm{m}$ calpain, $\mu$-calpain, and calpaina $3 ; \mu$-calpain activity decreases sharply in the first days after slaughter, while $\mathrm{m}$-calpain activity is stable (28). The National Institutes of Health issued detailed recommendations on the intake of long-chain $\mathrm{n}-3$ fatty acids, recommending that at least $650 \mathrm{mg} /$ day C20:5 n-3 and C22:6 n3, 2.22 g/day C18:3 n-3, and 4.44 g/day C18:2 n-6 should help reduce the risk of cardiovascular diseases (29). Although seafood is the main source of polyunsaturated fatty acid (PUFA) n-3 fatty acids in the human diet, studies clearly indicate that red meat can also be an excellent source.

It is the intent of this review to synthesize and summarize the currently available information about beef quality as well as to discuss the interpretation of the results.

\section{DIETETIC PROPERTIES OF BEEF}

The share of individual fatty acid families in bovine intramuscular fat is as follows: $38-44 \%$ are saturated fatty acids (SFA), $46 \%$ are monounsaturated fatty acids (MUFA), and $10 \%$ are PUFA (18). Studies have shown that C12:0, C14:0, and $\mathrm{C} 16: 0$ have atherogenic properties, while C14:0, C16:0, and C18:0 have thrombogenic properties (30). MUFA as well as fatty acids from the families PUFA n-3 and PUFA n- 6 have anti-atherogenic and antithrombogenic effects. The quality of meat varies, and that variability is determined by both individual and environmental factors: age, live weight, fatness degree, plane of nutrition, and concentrate/roughage ratio $(18,29,31)$. Barton et al. (32) revealed that supplementation of sunflower seed increased the proportions of C18:2 n-6 and C18:2 cis-9 trans-11 and PUFA/SFA ratio and decreased the fatty acid atherogenicity in meat lipids. Pasture-finished cattle produce beef with a greater concentration of PUFA n-3 fatty acids than concentrate-fed cattle (33-35).

Crude glycerin can be used as a long-term substitute for barley meal in concentrations of up to $10 \%$ of dry matter in the diets of finishing bulls (36). The different quantities of glycerin in ruminants might be either converted to volatile fatty acids, especially butyrate and propionate at the expense of acetate, or directly absorbed from the digestive system and act as a gluconeogenesis precursor in the liver $(37,38)$. Glycerin supplementation may also improve forage digestibility and increase the production of microbial proteins in the rumen in a dose-dependent manner (39). Glycerin addition in ruminant diet has also been estimated in several studies with cattle (40-42), but the results for carcass characteristics and growth performance were inconclusive and ambiguous. The study of Barton et al. (36) showed that the partial replacement of barley with crude glycerine did not have a significant influence on the feed conversion ratio and daily gain of bulls. Similar to these results, Mach et al. (41) concluded that glycerine is a good energy ingredient replacement in the finishing diet of bulls, with no negative impact on feed efficiency and daily gains. Positive effects on feed efficiency and daily gains have been noted when dietary glycerin supplementation in steer and heifer finishing diets was included at $<10 \%$ of dry matter ( 40 , 42). Conversely, reduced feed efficiency and daily gains were noted when a diet containing $16 \%$ glycerin was used (42). Dietary glycerin supplementation did not change the carcass composition, slaughter characteristic, and chemical composition of musculus longissimus lumborum (MLL). However, it is noteworthy that all the fatness characteristics (internal fats, carcass separable fat, carcass fatness score, fat thickness on MLL, and petroleum ether extract of MLL) were numerically higher in glycerin-fed cattle (36).

The formation of the fatty acid profile is also related to the type of muscle. Studies have shown that the SFA concentration in femorsis biceps is more than 3 times higher than in semimembranous biceps. When analyzing the MUFA and PUFA contents, we can also see the advantage of biceps femorsis over semimembranous biceps (31).

\section{INFLUENCE OF BREED ON BEEF AND CARCASS PROPERTIES}

Breed differences in the muscle lipid fatty acid profile are often affected by the intramuscular fat content (due to differences in the fatty acid composition of the major muscle lipid fractions) $(12,16)$. Differences in the fatty acid composition of crossbred cattle were determined by genetic differences, rather than by differences in the content of intramuscular fat (43). Iwanowska and Pospiech (44) revealed that variations in cattle slaughter value can be as high between breeds as within a single breed; they found that the culinary meat amount obtained from carcasses may be increased by a modification in the carcass cutting system.

The musculature of an animal is influenced by many genes, one of which is the gene coding myostatin, whose polymorphism is associated with the occurrence of a double-muscled phenotype in Belgian Blue and Piemontese cattle. The Piemontese breed has a deletion of 11 nucleotides in exon 3 of the gene located on chromosome 2. This mutation caused the loss of 3 amino acids (275-277) in the polypeptide protein chain. Exon 3 has an open reading frame; the deletion caused it to move and create a stop codon after 287 amino acids. This led to a shortening of the protein chain and thus a loss of protein function (45). The relative increase in the number of fibers is observed in early pregnancy (46), with the results in the calf having almost twice as many muscle fibers at the time of birth. Belgian Blue animals have an 
increased ability to convert feed into lean muscle and produce a higher percentage of the most desirable cuts of meat. These animals have less bone, less fat, and on average $20 \%$ more muscle compared with double-muscled (DBM) and normal Belgian Blue bulls, and it was found that the meat of DBM bulls contained about 3 times more PUFA content (27.5 vs. $11.3 \mathrm{~g} / 100 \mathrm{~g}$ of FA) compared with normal animals (47).

The dietary and healthy benefits to humans are determined by the long-chain PUFA traits due to their anti-atherogenic, antiinflammatory, and antithrombotic effects. Meat is one of the most nourishing dietary sources (48). The $\mathrm{n}-6 / \mathrm{n}-3$ ratio is considered as a risk factor in coronary heart disease and cancer disease when it is higher than 4 (49). This indicator was significantly lower in the LCS (based on lucerne silage and legume-cereal mixture silage) bulls and well below the recommended maximum (34). A number of reports showed variations in beef cattle performance and carcass characteristics under similar production conditions due to breed effects in crossbreeding experiments (50-53). Barton et al. (5) evaluated the effects of breed on live weight gain, carcass composition, and slaughter characteristics, comparing these with those of Aberdeen Angus, Charolais, Hereford, and Simmental bulls. The target slaughter live weights were fixed at $550 \mathrm{~kg}$ for earlier-maturing breeds, i.e., Aberdeen Angus and Hereford, and at $630 \mathrm{~kg}$ for later-maturing breeds, i.e., Charolaise and Simmental. Charolaise and Simmental gained faster than Aberdeen Angus, while Hereford was intermediate. More valuable cuts were in Charolaise and Simmental. Hereford breed was characterized by the highest separable fat percentage. The thinnest subcutaneous fat over $\mathrm{m}$. longissimus lumborumet thoracis was recorded in Charolaise and Simmental than in Aberdeen Angus and Hereford. The results of the experiment showed that earlier-maturing bulls had a lower live weight and produced more fat and less percentage of meat from high-priced cuts in comparison with later-maturing breeds.

Nogalski et al. (54) defined the impact of genotype and carcass conformation class on the slaughter quality of 200 young bulls. In this group were 108 crossbred bulls and 92 Holstein-Friesians (HF). They were slaughtered at the age of 21-22 months. The results of the classification placed $61.11 \%$ of crossbred beef bulls in R class (in EUROP system), and 56.53\% of HF bulls were classified as $\mathrm{O}$. Using the same conformation classes, the HF bulls were characterized by a lower slaughter quality than the crossbred beef bulls which had a higher content of fat by $0.42 \%$ and also better fatty acid composition of meat. The carcasses from too young cattle were characterized by a lower content of muscles, only slight marbling, and poor subcutaneous fat cover. According to Kaczmarek (55), early-maturing breeds like Hereford and Aberdeen Angus tend to deposit fat earlier and are intensively feed with concentrates, which causes their carcasses to be fatter. The late-maturing breeds, like Chianina, Charolaise, Limousine, or Piemontese, manifest a higher tendency to accumulate protein rather than fat. Those breeds are predisposed for intensive fattening due to their impressive daily weight gains. On the other hand, Nogalski et al. (34) concluded that crossbred animals had an advantage over HF bulls as exposed by the higher content of functional fatty acids in meat fat.
The physiological groups have a strong influence on the composition of carcass tissues (56). Heifers reach the finishing phase before steers, who, in turn, reach the finishing phase before bulls (57). Pogorzelska-Przybyłek et al. (58) reported that, in semi-intensive production systems, steers performed better than bulls, and $\mathrm{HF} \times \mathrm{HH}$ crosses were more suitable than $\mathrm{HF} \times$ Limousin and HF $\times$ Charolais crosses. The quality of carcasses is influenced by two important factors, e.g., final body weight and age of the animals. Based on the slaughter value, Nogalski et al. (54) determined the most efficient finishing weight of young Polish Holstein Friesian $\times$ Limousine crossbred bulls and steers. Upon comparing the slaughter results of bulls and steers, it was shown that bulls have a better slaughter value, $1.07-2.60 \%$ higher percentage of carcass dressing, lower carcass fatness, and higher carcass conformation. On the other hand, Sharman et al. (59) showed that a moderate level of energy intake and lower sensitivity to changes in dietary protein levels weigh in favor of steers. Additionally, Blanco et al. (60) reported that fattening steers and especially heifers can lead to improved fat-related meat quality traits in lean breeds.

The slaughter performance and fattening of Polish Red Cattle bulls were investigated by Łappa et al. (61). They reported that the carcasses of animals 12 months of age contained $68.12 \%$ meat and $13.25 \%$ fat, while 15 -month-old animals had $66.61 \%$ meat and $15.12 \%$ fat, respectively. Nahlik (62) reported that the carcasses of 15-month-old Polish Red bulls reached 71.01\% meat and $12.24 \%$ fat. Oprzadek et al. (63) reported newer results for tissue composition of 12-month-old Polish Red bull carcasses which had $71.91 \%$ meat and $9.76 \%$ fat. The analysis of the Polish Red Cattle slaughter value shows similar traits to the Limousine breed (amount and quality of meat) and that it strongly exceeds that of the Hereford breed. Additionally, Pogorzelska-Przybyłek et al. (58) reported that dairy-beef crosses should be slaughtered at 21 months of age to improve the carcass quality.

The study carried out by Daszkiewicz and Wajda (64) showed that the dressing percentages of Black and White breed and Limousine breed were respectively, 50.22 and $61.84 \%$. Monsón et al. (65) reported a similar result $(61.40 \%)$ for the Limousine breed. Both results of Daszkiewicz and Wajda (66) and Monsón et al. (65) have been confirmed by Oprzadek et al. (63) in a study on 12-month-old bulls. The dressing percentage of Limousine was higher (59.25\%) than the values obtained for Black and White (50.94\%) and Hereford breeds (54.92\%). Miciński et al. (67) reported $63.86 \%$ dressing percentage of the Limousine breed and $55.30 \%$ of the Hereford breed. As shown by Malau-Aduli et al. (68), in the adipose tissue of Limousine and Jersey cattle, the total MUFA content tended to increase with age.

Many researchers provide that the best moment to terminate the fattening of a herd is when the animals attain the so-called slaughtering maturity, i.e., best musculature and carcass tissue composition and developed culinary elements $(66,69)$. Feeds rich in proteins should be used during the most intensive muscle tissue development. It is not recommended to slaughter animals too early before they attain appropriate slaughter maturity. 


\section{INFLUENCE OF FEEDING SYSTEM ON BEEF AND CARCASS PROPERTIES}

Differences in carcass composition between animals fed different diets can be attributed to the diet composition or the effect of growth rate. Bulls and steers fed concentrates, forage ad libitum, or finished on concentrates after grazing were slaughtered at a similar weight and had a similar dressing percentage and degree of fat cover (16). Garcia et al. (70) reported total CLA values in the longissimus dorsi muscle of 5.8 vs. $3.1 \mathrm{mg} / \mathrm{g}$ FAs in steers fed on pasture supplemented with cracked corn grain (1\% live weight) compared to a corn-based concentrate with alfalfa hay. Additionally, Rutherford et al. (71) reported that a production system including a grazing period within bull beef production may be a more sustainable approach to producing Holstein bulls.

Other factors, such as nutrition, have also been found to influence the meat quality due to their regulatory effect on biological processes in muscle and on fat deposition $(29,32,72)$. Various feeding strategies are often used to increase the content of PUFA n-3 fatty acid and to improve beef intramuscular PUFA $n-6 /$ PUFA $n-3$ ratio $(2,4,73-77)$. The strategy for the rearing and feeding of cattle for slaughter should therefore aim at reducing the SFA content and increasing the PUFA and MUFA levels $(18,30)$. Cattle forage typically contain 1-4\% lipids, mostly PUFA, including $\alpha$-linoleic and acid linoleic acid (29). Fredriksson-Eriksson and Pickova (31) reported that a higher $\alpha$-linoleic concentration in meat from pasture-fed bulls can be enhanced by its association with the thylakoid membranes in chloroplasts that can protect against ruminal biohydrogenation. Ground grass-fed beef had a greater concentration of C18:2 cis-9 trans-11 and C18:1 trans-11 (29, 31). French et al. (78) reported that decreasing the proportion of concentrate in the diet, which effectively increased grass intake, caused a linear decrease in the concentration of SFA and in the $\mathrm{n}-6 / \mathrm{n}-3$ ratio and a linear increase in the PUFA/SFA ratio.

Replacement maize silage with alfalfa silage and legumecereal mixture silage conspicuously increased the C18:3n-3 dietary intake (32). Nogalski et al. (34) reported that the low proportion of PUFA in the FA profile could be related to the age of bulls at slaughter (21-22 months). The PUFA content of intramuscular fat in $\mathrm{m}$. longissimus dorsi decreases with age, reaching $25.5 \%$ at 7 months, $18.4 \%$ at 14 months, and $13.6 \%$ at 19 months (79). The recommended PUFA n6/PUFA n-3 ratio by the FAO and WHO is around 5.0 (15). The introduction of supplements rich in PUFA (80-82) prevents or minimizes biohydrogenation and affects the carcass characteristics (83). Albertí et al. (84) found that addition of $5 \%$ linseed decreased the dressing rate without changing the daily gain or classification of carcasses. Additionally, a lower $n-6 / n-3$ fatty acid ratio has been observed in muscle from grass-fed animals compared to that in concentrate-fed animals (32).

Murphy et al. (85) reported that increased toe net growth does not adversely affect the walking ability. Despite the greater toe net growth in bulls accommodated on rubber flooring, there was no effect of floor type on locomotion score, suggesting that the increased toe net growth does not adversely affect the walking ability.

\section{EFFECT OF SEX ON BEEF AND CARCASS QUALITY}

The research carried out by Bureš and Barton (86) showed the impact of the sex and age of slaughtered animals on carcass composition, feed intake, growth, and quality of MLL meat on Simmental $\times$ Charolaise heifers and bulls. The results showed that the body weight of the bulls increased, while the daily dry matter consumption was higher. They obtained a significant interaction between sex $\times$ slaughter age and feed conversion ratio which decreased in older heifers. The bull carcasses were leaner with a higher total meat proportion. Bull carcasses obtained a higher proportion of the high-priced shoulder meat, and heifer carcasses had a better meat proportion of loin and rump. The proportion of bones and high-priced meat has decreased with the age of animals, whose carcasses were also fatter. Bulls had less dry matter, proteins, and intramuscular fat and more collagen than heifers.

Richardson and Herd (87) indicate differences between age and sex groups in terms of feed conversion ratio, which is caused by a few biological mechanisms, e.g., protein turnover, different body composition, or tissue metabolism of animals. The higher internal fat deposition in the heifer group determined a lower killing-out proportion. The same conclusions were reported by Steen (88), Frickh et al. (89), and Velik et al. (90). The fatness characteristics were affected by slaughter age and sex. Bulls had a lower proportion of fat in their body composition than heifers. Both groups produced more fat with increasing age; however, this trend was more intense for heifers.

The different meat distribution in bull and heifer carcasses showed a more intensive meat expansion in the forequarter in bulls and hindquarter in heifers. The respective research of Steen and Kilpatrick (91) and Link et al. (92) comparing the carcasses of different breeds of bulls and heifers were in agreement with the results of Bureš and Barton (86). With age, the proportions of high-value meat are decreasing, causing a fall of high/low-priced meat ratio, e.g., the MLL content per $100 \mathrm{~kg}$ of slaughter weight is smaller; the fat content is also higher with age. Harper and Pethick (93) documented the influence of sex hormones on intramuscular adipocyte development. This study showed almost twice higher intramuscular fat content in heifers (petroleum ether extract) than in bulls of the same age. The papers discussed have shown significant differences between both sexes slaughtered at two fixed ages in terms of performance, parameters of meat quality, and carcass traits. The heifers grew slower and less effectively, had a lower killing-out proportion, and produced fatter carcasses with a lower total meat proportion than the bulls. The MLL of bulls compared to heifers contained more intramuscular fat, less protein, less dry matter, and more total collagen, which was assessed by the sensory panel as more acceptable. The increase of slaughter age by 4 months resulted, especially in heifers, in reduced daily gain and feed conversion ratio as well as markedly higher fatness characteristics. Therefore, 
such an extension of the finishing period could not be considered advantageous for Charolaise $\times$ Simmental heifers fed a highenergy diet. Shifting the term of slaughter for 4 months caused a decrease of feed conversion and daily gains, especially in the heifer group. Therefore, application of high-energy diet in the finishing period was not efficient to Charolaise $\times$ Simmental heifers. Additionally, Prado et al. (94) reported that the finishing of young bulls in feedlot is to be recommended since the animals produce carcasses with higher amounts of edible meat and higher yields of commercial cuts, thus allowing for a better price for the carcass.

Many researchers $(6,95,96)$ indicate sex as an important factor causing differences in meat quality. Additionally, heifer carcasses also have a higher fat/meat proportion $(97,98)$.

\section{CONCLUSION}

There is a well-recognized impact of breed on lipid metabolism in tissues and dietary fatty acid content in bovine muscles. Based on the literature reviewed, it can be concluded that the quality

\section{REFERENCES}

1. Listrat A, Lebret B, Louveau I, Astruc T, Bonnet M, Lefaucheur L, et al. How muscle structure and composition influence meat and flesh quality. Sci World J. (2016) 2016:3182746. doi: 10.1155/2016/3182746

2. Chail A. Effects of Beef Finishing Diets and Muscle Type on Meat Quality, Fatty Acids and Volatile Compounds. Master of Science, Utah State University Logan, Utah (2015).

3. Domaradzki P, Florek M, Litwińczuk A. Czynniki kształtujace jakość miesa wołowego. Wiadom. Zootech. (2016). p. 160-70.

4. Barton L, Marounek M, Kudrna V, Bureš D, Zahradkova R. Growth performance and fatty acid profiles of intramuscular and subcutaneous fat from Limousin and Charolais heifers fed extruded linseed. Meat Sci. (2007) 76:517-23. doi: 10.1016/j.meatsci.2007.01.005

5. Barton L, Rehak D, Teslik V, Bures D, Zahradkova R. Effect of breed on growth performance and carcass composition of Aberdeen Angus, Charolais, Hereford and Simmental bulls. Czech J Anim Sci. (2006) 51:4753. doi: 10.17221/3908-CJAS

6. Jurczak ME. Towaroznawstwo produktów zwierzecych: ocena jakości miesa. Wydaw. SGGW (2004).

7. Gigli S, Failla S, Iacurto M, Contò M, Sañudo C, Olleta J, et al. Performance at slaughter and beef quality characteristics of some Mediterranean beef breeds compared to Central and North European breeds (GemQual EU Project). In: Proceedings of Seminar of the Scientific Professional Network on Mediterranean Livestock Farming (RME). (2006). p. 173-82.

8. Pesonen M, Honkavaara M, Huuskonen AK. of breed on production, carcass traits and meat quality of Aberdeen Angus, Limousin and Aberdeen Angus $\times$ Limousin bulls offered a grass silage-grain-based diet. Agric Food Sci. (2012) 21:361-9. doi: 10.23986/afsci.6520

9. Duckett S, Neel J, Lewis RM, Fontenot J, Clapham W. Effects of forage species or concentrate finishing on animal performance, carcass and meat quality. $J$ Anim Sci. (2013) 91:1454-67. doi: 10.2527/jas.2012-5914

10. Wu G, Cross H, Gehring K, Savell J, Arnold A, McNeill S. Composition of free and peptide-bound amino acids in beef chuck, loin, round cuts. J Anim Sci. (2016) 94:2603-13. doi: 10.2527/jas.2016-0478

11. Listrat A, Pissavy AL, Micol D, Jurie C, Lethias C, David P, et al. Collagens XII and XIV: two collagen types both associated with bovine muscle and intramuscular lipid metabolism. Livestock Sci. (2016) 187:806. doi: 10.1016/j.livsci.2016.02.009 of beef is largely related to sex, age of the slaughtered animals, and feeding system. All of these factors must be taken into consideration when addressing improvements to the nutritional quality of beef.

\section{AUTHOR CONTRIBUTIONS}

TS: contributed to conceptualization, searching of literature, writing-original draft, writing-review and editing, project administration, and supervision. KP: contributed to conceptualization, writing-original draft, and writing-review and editing. MG, JS, PK, and PS: contributed to searching of literature. GG: contributed to visualization. All authors read and approved the final manuscript.

\section{FUNDING}

The authors acknowledge the financial support for this project provided by transnational funding bodies, being partners of the FP7 ERA-net project, CORE Organic Plus, and European Commission co-fund.

12. De Smet S, Raes K, Demeyer D. Meat fatty acid composition as affected by fatness and genetic factors: a review. Anim Res. (2004) 53:8198. doi: 10.1051/animres:2004003

13. Keane MG. Relative Tissue Growth Patterns and Carcass Composition in Beef Cattle; Teagasc. (2011). Available online at: http://hdl.handle.net/11019/1183

14. Calvo JH, Iguacel LP, Kirinus JK, Serrano M, Ripoll G, Casasus I, et al. A new single nucleotide polymorphism in the calpastatin (CAST) gene associated with beef tenderness. Meat Sci. (2014) 96:77582. doi: 10.1016/j.meatsci.2013.10.003

15. Kołczak T. Beef Quality. Zywność. Nauka. Technologia. Jakość. (2008) 56, 5-22.

16. Przysucha T, Abramowicz P, Balcerak M, Brzozowski P, Gołebiewski $\mathrm{M}$, Grodzki $\mathrm{H}$, et al. Miesne uzytkowanie bydła; Wydawnictwo SGGW,Warszawa (2018).

17. Hunt $M$, Hedrick $H$. Chemical, physical and sensory characteristics of bovine muscle from four quality groups. J Food Sci. (1977) 42:71620. doi: 10.1111/j.1365-2621.1977.tb12586.x

18. Mohan A. Myoglobin Redox Form Stabilization: Role of Metabolic Intermediates and NIR Detection. Kansas State University (2009).

19. Mancini R, Hunt M. Research in meat color. Meat Sci. (2005) 71:10021. doi: 10.1016/j.meatsci.2005.03.003

20. McKenna D, Mies P, Baird B, Pfeiffer K, Ellebracht J, Savell J. Biochemical and physical factors affecting discoloration characteristics of 19 bovine muscles. Meat Sci. (2005) 70:665-82. doi: 10.1016/j.meatsci.2005.02.016

21. Khan MI, Jung S, Nam KC, Jo C. Postmortem aging of beef with a special reference to the dry aging. Kor J Food Sci Anim Resour. (2016) 36:15969. doi: 10.5851/kosfa.2016.36.2.159

22. Rutherford NH, Lively FO, Arnott G. Evaluation of rumen temperature as a novel indicator of meat quality: rumen temperature, and haematological indicators of stress during the pre-slaughter period as predictors of instrumental meat quality in bulls. Meat Sci. (2019) 158:107913. doi: 10.1016/j.meatsci.2019.107913

23. Garcia PT, Casal JJ. Effect of dietary plant lipids on conjugated linoleic acid (CLA) concentrations in beef and lamb meats. In: El-Shemy HA, editor. Soybean-Bio-Active Compounds. Vienna: InTech (2013). p. 135-59. doi: $10.5772 / 52608$

24. Laborde FL, Mandell IB, Tosh JJ, Wilton JW, Buchanan-Smith JG. Breed effects on growth performance, carcass characteristics, fatty acid composition, and palatability attributes in finishing steers. J Anim Sci. (2001) 79:35565. doi: $10.2527 / 2001.792355 \mathrm{x}$ 
25. Cuvelier C, Clinquart A, Hocquette JF, Cabaraux JF, Dufrasne I, Istasse L, et al. Comparison of composition and quality traits of meat from young finishing bulls from Belgian Blue, Limousin and Aberdeen Angus breeds. Meat Sci. (2006) 74:522-31. doi: 10.1016/j.meatsci.2006.04.032

26. Aldai N, Dugan MER, Najera AI, Osoro K. N-6 and n-3 fatty acids in different beef adipose tissues depending on the presence or absence of the gene responsible for double-muscling. Czech J Anim Sci. (2008) 53:51522. doi: 10.17221/365-CJAS

27. Sensky P, Parr T, Bardsley R, Buttery P. The relationship between plasma epinephrine concentration and the activity of the calpain enzyme system in porcine longissimus muscle. J Anim Sci. (1996) 74:3807. doi: $10.2527 / 1996.742380 \mathrm{x}$

28. Pandurangan M, Hwang I. The role of calpain in skeletal muscle. Anim Cells Syst. (2012) 16:431-7. doi: 10.1080/19768354.2012.724708

29. Leheska J, Thompson L, Howe J, Hentges E, Boyce J, Brooks J, et al. Effects of conventional and grass-feeding systems on the nutrient composition of beef. $J$ Anim Sci. (2008) 86:3575-85. doi: 10.2527/jas.2007-0565

30. de Almeida JC, Perassolo MS, Camargo JL, Bragagnolo N, Gross JL. Fatty acid composition and cholesterol content of beef and chicken meat in Southern Brazil. Revist Brasileira Ciênc Farmacêut. (2006) 42:10917. doi: 10.1590/S1516-93322006000100012

31. Fredriksson-Eriksson SF, Pickova J. Fatty acids and tocopherol levels in M. Longissimus dorsi of beef cattle in Sweden-A comparison between seasonal diets. Meat Sci. (2007) 76:746-54. doi: 10.1016/j.meatsci.2007.02.021

32. Barto,n L, Marounek M, Kudrna V, Bures D, Zahradkova R. Growth, carcass traits, chemical composition and fatty acid profile in beef from Charolais and Simmental bulls fed different types of dietary lipids. J Sci Food Agric. (2008) 88:2622-30. doi: 10.1002/jsfa.3381

33. Dewhurst RJ, Scollan ND, Lee MR, Ougham HJ, Humphreys MO. Forage breeding and management to increase the beneficial fatty acid content of ruminant products. Proc Nutr Soc. (2003) 62:329-36. doi: 10.1079/PNS2003241

34. Nogalski Z, Wroński M, Wielgosz-Groth Z, Purwin C, Sobczuk-Szul M, Mochol M, et al. The Effect of Carcass Conformation Class (Europ System) on the Slaughter Quality of Young Crossbred Beef Bulls and HolsteinFriesians/Porównanie wartości rzeznej buhajków mieszańców miesnych i holsztyno-fryzów w zalezności od klasy uformowania w systemie EUROP. Ann Anim Sci. (2013) 13:121-31. doi: 10.2478/v10220-0120064-9

35. Barto,n L, Bures D, Kudrna V. Meat quality and fatty acid profile of the musculus longissimus lumborum in Czech Fleckvieh, Charolais and Charolais x Czech Fleckvieh bulls fed different types of silages. Czech J Anim Sci. (2010) 55:479-87. doi: 10.17221/1713-CJAS

36. Barton L, Bures D, Homolka P, Jancik F, Marounek M, Rehak D. Effects of long-term feeding of crude glycerine on performance, carcass traits, meat quality, and blood and rumen metabolites of finishing bulls. Livestock Sci. (2013) 155:53-9. doi: 10.1016/j.livsci.2013.04.010

37. Krehbiel C. Ruminal and physiological metabolism of glycerin. J Anim Sci. (2008) 86:392.

38. Rémond B, Souday E, Jouany J. In vitro and in vivo fermentation of glycerol by rumen microbes. Anim Feed Sci Technol. (1993) 41:12132. doi: 10.1016/0377-8401(93)90118-4

39. Wang C, Liu Q, Huo W, Yang W, Dong K, Huang Y, et al. Effects of glycerol on rumen fermentation, urinary excretion of purine derivatives and feed digestibility in steers. Livestock Sci. (2009) 121:15-20. doi: 10.1016/j.livsci.2008.05.010

40. Pyatt N, Doane P, Cecava M. Effect of crude glycerin in finishing cattle diets. Proc J Dairy Sci. (2007) 85:412.

41. Mach N, Bach A, Devant M. Effects of crude glycerin supplementation on performance and meat quality of Holstein bulls fed high-concentrate diets. J Anim Sci. (2009) 87:632-8. doi: 10.2527/jas.2008-0987

42. Parsons G, Shelor M, Drouillard J. Performance and carcass traits of finishing heifers fed crude glycerin. J Anim Sci. (2009) 87:6537. doi: $10.2527 /$ jas.2008-1053

43. Graham J, Bernaud E, Deland M. Sire and dam breed effects on fatty acid profiles in the longissimus dorsi muscle and subcutaneous fat of beef cattle. Aust J Exp Agric. (2006) 46:913-9. doi: 10.1071/EA05301
44. Iwanowska A, Pospiech E. Comparison of slaughter value and muscle properties of selected cattle breeds in Poland-Review. Acta Sci Polonor Tech Alimentar. (2010) 9:7-22.

45. Dunner S, Miranda ME, Amigues Y, Cañón J, Georges M, Hanset R, et al. Haplotype diversity of the myostatin gene among beef cattle breeds. Genet Sel Evol. (2003) 35:103-18. doi: 10.1186/1297-9686-35-1-103

46. Swatland H, Kieffer NM. Fetal development of the double muscled condition in cattle. J Anim Sci. (1974) 38:752-7. doi: 10.2527/jas1974.384752x

47. Raes K, De Smet S, Demeyer D. Effect of double-muscling in Belgian Blue young bulls on the intramuscular fatty acid composition with emphasis on conjugated linoleic acid and polyunsaturated fatty acids. Anim Sci. (2001) 73:253-60. doi: 10.1017/S1357729800058227

48. Givens DI, Khem KE, Gibbs RA. The role of meat as a source of n-3 polyunsaturated fatty acids in the human diet. Meat Sci. (2006) 74:20918. doi: 10.1016/j.meatsci.2006.04.008

49. Webb EC, O'Neill H. The animal fat paradox and meat quality. Meat Sci. (2008) 80:28-36. doi: 10.1016/j.meatsci.2008.05.029

50. Kogel J, Pickl M, Rott J, Hollwich W, Sarreiter R, Mehler N. Crossbreeding trial with Charolais, Blond d'Aquitaine and Limousin on Fleckvieh cows - 2nd communication: Carcass yield and carcass quality. Zuchtungskun. (2000) 72:201-16.

51. Wheeler T, Cundiff L, Shackelford S, Koohmaraie M. Characterization of biological types of cattle (Cycle VII): Carcass, yield, and longissimus palatability traits. J Anim Sci. (2005) 83:196-207. doi: 10.2527/2005.831196x

52. Hyslop JJ, Keatinge R, Chapple DG. Voluntary food intake, live-weight gain, carcass quality and food conversion in contrasting genotypes of weaned suckler-bred bulls finished intensively on a cereal-based diet. Anim Sci. (2006) 82:117-24. doi: 10.1079/ASC20054

53. Steinwidder A, Guggenberger T, Schauer A, Roemer A, Ibi G, Frickh J. Effect of ration, sex and breeding on fattening performance of cattle from suckler cow systems. Zuchtungskun. (2007) 79:128-41.

54. Nogalski Z, Wielgosz-Groth Z, Purwin C, Sobczuk-Szul M, Mochol M, Pogorzelska-Przybylek P, et al. Effect of slaughter weight on the carcass value of young crossbred ('Polish Holstein Friesian' x 'Limousin') steers and bulls. Chilean J Agric Res. (2014) 74:59-66. doi: 10.4067/S0718-58392014000100010

55. Kaczmarek A. Hodowla i chów bydła. Poznań AR: Poznań (1994).

56. Aricetti JA, Rotta, P. P.; Prado RM, Perotto D, Moletta JL, Matsushita M, et al. Carcass characteristics, chemical composition and fatty acid profile of Longissimus muscle of bulls and steers finished in a pasture system bulls and steers finished in pasture systems. Asian Australas. J Anim. Sci. (2008) 21:1441-8. doi: 10.5713/ajas.2008.80061

57. Rotta PP, Prado RM, Prado IN, Valero MV, Visentainer JV, Silva RR. The effects of genetic groups, nutrition, finishing systems and gender of Brazilian cattle on carcass characteristics and beef composition and appearance: a review. Asian Austr J Anim Sci. (2009) 22:171834. doi: 10.5713/ajas.2009.90071

58. Pogorzelska-Przybyłek P, Nogalski Z, Sobczuk-Szul M, Purwin C, Momot M. Carcass characteristics of grass-fed crossbred bulls and steers slaughtered at two different ages. Can J Anim Sci. (2018) 98:376-85. doi: 10.1139/cjas-2017-0148

59. Sharman ED, Lancaster PA, McMurphy CP, Garmyn AJ, Pye BJ, Mafi GG, et al. Effect of rate of body weight gain in steers during the stocker phase. I. Growth, partitioning of fat among depots, and carcass characteristics of growingfinishing beef cattle. J Anim Sci. (2013) 91:4322-35. doi: 10.2527/jas.2012-5440

60. Blanco M, Ripoll G, Delavaud C, Casasús I. Performance, carcass and meat quality of young bulls, steers and heifers slaughtered at a common body weight. Livest Sci. (2020) 240:104156. doi: 10.1016/j.livsci.2020.104156

61. Lappa H, Romer J, Lewinska L. Porownanie przydatnosci opasowej i rzeznej buhajkow rasy czarno-bialej, czerwono-bialej, polskiej czerwonej i mieszancow dc X pc opasanych do wieku 12 i 15 miesiecy. Rocz Nauk Rol. (1975) 96-B-4:23-39.

62. Nahlik KJ. Wplyw krzyzowania bydła polskiego czerwonego $z$ bydłem czerwono-bialym i simentalskim na przydatność opasowa i rzezna mieszańców pokolenia F1. (1973). Państwowe Wydawnictwo Rolnicze i Leśne.

63. Oprzadek J, Dymnicki E, Reklewski Z. Zmiany tempa wzrostu i skladu tkankowego tuszy mlodego bydla w zaleznosci od rasy. Rocz Nauk Polskiego Tow Zootech. (2007) 3:103-9. 
64. Daszkiewicz T, Wajda S. Masa przedubojowa buhajkow a ich wydajnosc rzezna i jakosc miesa. Gospodar Mies. (2002) 54:16-8.

65. Monson F, Sanudo C, Sierra I. Influence of breed and ageing time on the sensory meat quality and consumer acceptability in intensively reared beef. Meat Sci. (2005) 71:471-9. doi: 10.1016/j.meatsci.2005.0 4.026

66. Daszkiewicz T, Wajda S. Wartość rzezna oraz jakość miesa buhajków rasy czarno-białej i limousine. Rocz Instyt Przem Miesn Tłuszcz. (2002) 39:57-65.

67. Micinski J, Klupczynski J, Ostoja H, Cierach M, Dymnicka M, Lozicki A, et al. Wplyw rasy i zywienia buhajkow na wyniki klasyfikacji ich tusz w systemie EUROP oraz na ocene tekstury miesa. Zywn Nauk Tech Jak Sup. (2005) 3:147-56.

68. Malau-Aduli A, Siebert B, Bottema C, Pitchford W. A comparison of the fatty acid composition of triacylglycerols in adipose tissue from Limousin and Jersey cattle. Aust J Agric Res. (1997) 48:715-22. doi: 10.1071/A96083

69. Brzozowski P. Technologie produkcji zywca wołowego. Hortpress, Warszawa (2006).

70. Garcia PT, Pensel NA, Sancho AM, Latimori NJ, Kloster AM, Amigone MA, et al. Beef lipids in relation to animal breed and nutrition in Argentina. Meat Sci. (2008) 79:500-8. doi: 10.1016/j.meatsci.2007.10.019

71. Rutherford NH, Gordon AW, Arnott G, Lively FO. The effect of beef production system on the health, performance, carcass characteristics, and meat quality of Holstein Bulls. Animals. (2020) 10:1922. doi: 10.3390/ani10101922

72. Scollan N, Hocquette JF, Nuernberg K, Dannenberger D, Richardson I, Moloney A. Innovations in beef production systems that enhance the nutritional and health value of beef lipids and their relationship with meat quality. Meat Sci. (2006) 74:17-33. doi: 10.1016/j.meatsci.2006.05.002

73. French P, O'riordan E, Monahan F, Caffrey P, Vidal M, Mooney M, et al. Meat quality of steers finished on autumn grass, grass silage or concentrate-based diets. Meat Sci. (2000) 56:173-80. doi: 10.1016/S0309-1740(00)00037-1

74. Choi N, Enser M, Wood J, Scollan N. Effect of breed on the deposition in beef muscle and adipose tissue of dietary n-3 polyunsaturated fatty acids. Anim Sci. (2000) 71:509-19. doi: 10.1017/S1357729800055417

75. Vatansever L, Kurt E, Enser M, Nute G, Scollan N, Wood J, et al. Shelf life and eating quality of beef from cattle of different breeds given diets differing in n-3 polyunsaturated fatty acid composition. Anim Sci. (2000) 71:471-82. doi: 10.1017/S135772980005548X

76. French P, O'riordan E, Monahan F, Caffrey P, Mooney M, Troy D, et al. The eating quality of meat of steers fed grass and/or concentrates. Meat Sci. (2001) 57:379-86. doi: 10.1016/S0309-1740(00)00115-7

77. Lourenco M, Van Ranst G, Vlaeminck B, De Smet S, Fievez V. Influence of different dietary forages on the fatty acid composition of rumen digesta as well as ruminant meat and milk. Anim Feed Sci Technol. (2008) 145:41837. doi: 10.1016/j.anifeedsci.2007.05.043

78. French P, Stanton C, Lawless F, O'riordan E, Monahan F, Caffrey P, et al. Fatty acid composition, including conjugated linoleic acid, of intramuscular fat from steers offered grazed grass, grass silage, or concentrate-based diets. $J$ Anim Sci. (2000) 78:2849-55. doi: 10.2527/2000.78112849x

79. Lengyel Z, Husvéth F, Polgár P, Szabó F, Magyar L. Fatty acid composition of intramuscular lipids in various muscles of HolsteinFriesian bulls slaughtered at different ages. Meat Sci. (2003) 65:593-8. doi: 10.1016/S0309-1740(02)00252-8

80. Puppel K. The Influence of Fish Oil and Linseed Supplementation on the Fat and the Protein Fraction Content of Cow's Milk. Doctoral Thesis, SGGW, Warszawa (2011).

81. Puppel K, Nalecz-Tarwacka T, Kuczynska B, Golebiewski M, Kordyasz M, Grodzki H. The age of cows as a factor shaping the antioxidant level during a nutritional experiment with fish oil and linseed supplementation for increasing the antioxidant value of milk. J Sci Food Agric. (2012) 92:24949. doi: 10.1002/jsfa.5658

82. Puppel K, Kuczynska B, Nalecz-Tarwacka T, Grodzki H. Influence of linseed variety on fatty acid profile in cow's milk. J Sci Food Agric. (2013) 93:227680. doi: $10.1002 /$ jsfa. 6037

83. Castro T, Manso T, Mantecón A, Guirao J, Jimeno V. Fatty acid composition and carcass characteristics of growing lambs fed diets containing palm oil supplements. Meat Sci. (2005) 69:757-64. doi: 10.1016/j.meatsci.2004.11.008
84. Albert,í P, Beriain MJ, Ripoll G, Sarriés V, Panea B, Mendizabal JA, et al. Effect of including linseed in a concentrate fed to young bulls on intramuscular fatty acids and beef color. Meat Sci. (2014) 96:125865. doi: 10.1016/j.meatsci.2013.11.009

85. Murphy VS, Lowe DE, Lively FO, Gordon AW. The impact of floor type on lameness and hoof health of dairy origin bulls. Animal. (2018) 12:238290. doi: 10.1017/S1751731118000095

86. Bures D, Barton L. Growth performance, carcass traits and meat quality of bulls and heifers slaughtered at different ages. Czech J Anim Sci. (2012) 57:34-43. doi: 10.17221/5482-CJAS

87. Richardson E, Herd R. Biological basis for variation in residual feed intake in beef cattle. 2. Synthesis of results following divergent selection. Aust J Exp Agric. (2004) 44:431-40. doi: 10.1071/EA02221

88. Steen R. The effect of plane of nutrition and slaughter weight on growth and food efficiency in bulls, steers and heifers of three breed crosses. Livestock Prod Sci. (1995) 42:1-11. doi: 10.1016/0301-6226(95)00002-3

89. Frickh J, Steinwidder A, Baumung R. Effect of ration, sex and slaughter weight on slaughtering performance of Simmental cattle. Zuchtungskun. (2002) 74:362-75.

90. Velik M, Forschungszentrum LR, Steinwidder A, Frickh J. Effect of ration, sex, and breed on carcass performance and meat quality of cattle from suckler cow systems. In: Proceedings of 17 International Science Symposium on Nutrition of Domestic Animals' Zadravec-Erjavec Days' (17. Mednarodno znanstveno posvetovanje o prehrani domaèih 3/4ivali'Zadravèevi-Erjavèevi dnevi'), Radenci, 13-14 Nov 2008 (2008).

91. Steen RW, Kilpatrick DJ. Effects of pasture grazing or storage feeding and concentrate input between 5.5 and 11 months of age on the performance and carcass composition of bulls and on subsequent growth and carcass composition at $620 \mathrm{~kg}$ live weight. Anim Sci. (1998) 66:12941. doi: 10.1017/S1357729800008900

92. Link G, Willeke H, Golze M, Bergfeld U. Fattening- and slaughter performance of bulls and heifers of beef breeds and the cross PF breed German Angus x Simmental. Archiv Tierzucht-Archiv Anim Breed. (2007) 50:356-62. doi: 10.5194/aab-50-356-2007

93. Harper G, Pethick D. How might marbling begin? Aust J Exp. Agric. (2004) 44:653-62. doi: 10.1071/EA02114

94. Prado IN, Passetti RA, Rivaroli DC, Ornaghi MG, de Souza KA, Carvalho $\mathrm{CB}$, et al. Carcass composition and cuts of bulls and steers fed with three concentrate levels in the diets. Asian-Australas J Anim Sci. (2015) 28:130916. doi: 10.5713/ajas.15.0021

95. Cepin S, Cepon M. Genetic and environmental influences on carcass and meat quality of beef. Tehnol Mesa. (2001) 42:283-94.

96. Wajda S, Daszkiewicz T. Kulinarne mieso wolowe i ocena jego wlasciwosci organoleptycznych. Gospod Mięs. (2001) 53:18-22.

97. Sack E, Scholz W. Schlachtkörperzusammensetzung beim Rind. Kulmbacher Reihe. (1987) 7:87-117.

98. Pisula A, Tyburcy A, Dasiewicz K. Czynniki decydujace o jakości miesa wołowego. Gospod Mies. (2007) 1:4-11.

Conflict of Interest: The authors declare that the research was conducted in the absence of any commercial or financial relationships that could be construed as a potential conflict of interest.

Publisher's Note: All claims expressed in this article are solely those of the authors and do not necessarily represent those of their affiliated organizations, or those of the publisher, the editors and the reviewers. Any product that may be evaluated in this article, or claim that may be made by its manufacturer, is not guaranteed or endorsed by the publisher.

Copyright () 2022 Sakowski, Grodkowski, Gołebiewski, Slósarz, Kostusiak, Solarczyk and Puppel. This is an open-access article distributed under the terms of the Creative Commons Attribution License (CC BY). The use, distribution or reproduction in other forums is permitted, provided the original author(s) and the copyright owner(s) are credited and that the original publication in this journal is cited, in accordance with accepted academic practice. No use, distribution or reproduction is permitted which does not comply with these terms. 